\title{
The Labor Market Consequences of Hosting Refugees
}

\author{
Isabel Ruiz \\ Harris Manchester College \\ University of Oxford \\ isabel.ruiz@economics.ox.ac.uk \\ Carlos Vargas-Silva (contact author) \\ Centre on Migration, Policy and Society \\ University of Oxford \\ carlos.vargas-silva@compas.ox.ac.uk
}

There is a forthcoming revised version of this article in the Journal of Economic Geography: http://joeg.oxfordjournals.org/content/early/2015/06/12/jeg.lbv019.abstract

Visit the labour Market Impacts of Forced Migration (LAMFOR) project for updates: www.econforced.com

\section{Funding}

This document is an output from a project funded by the UK Department for International Development (DFID) and the Institute for the Study of Labor (IZA) for the benefit of developing countries. The views expressed are not necessarily those of DFID or IZA.

\section{Acknowledgement}

Thanks to Sonja Fransen, Wiliam A. Darity, Jr., participants of the Growth and Labour Markets in Low Income Countries Program Network Meeting, participants in seminars at the University of West England and University of Oxford and participants in the Allied Social Sciences Association conference (Boston), Centre for the Study of African Economies annual conference (University of Oxford) and the IS Academy: Migration and Development conference (Maastricht University) for helpful suggestions on earlier versions of this paper. 


\title{
The Labor Market Consequences of Hosting Refugees
}

\begin{abstract}
During the 1990s the northwestern region of Tanzania experienced a large inflow of refugees. Using panel data (pre and post refugee inflow) we estimate the labor market consequences of hosting those refugees. Results are consistent with immigration affecting the allocation of natives across economic activities. Greater exposure to the refugee shock resulted in Tanzanians having a higher likelihood of working in household shambas or caring for household livestock and a lower likelihood of working outside the household as employees. The latter effect was particularly strong for Tanzanians doing casual work before the shock. This coincides with anecdotal evidence of refugees concentrating in casual waged work in Tanzania and competing directly with Tanzanians for those jobs.
\end{abstract}

Keywords: forced migration, refugees, labor markets, Tanzania JEL Codes: F220, J610, O150 


\section{Introduction}

There is a large literature on the labor market impacts of migration (e.g. Borjas, 1994, 2003; Dustmann et al., 2005, 2013; Kerr and Kerr, 2011). Most of this literature deals with "voluntary" migration that involves individuals whose main motivation to move is to take advantage of new opportunities in other countries. However, a non-trivial share of global international migration is "forced" migration, that is, people moving to escape violence, conflict or oppression in their home countries. The United Nations Population Division (2013) estimates that there were 16 million international refugees worldwide in 2013. The majority of the world's refugees (over 80\%) are in developing countries (United Nations High Commission for Refugees, 2012). In recent years, there has been an important increase in forced migration as a result of political conflicts and the global number of forced migrants is at its highest peak since World War II (United Nations High Commission for Refugees, 2014).

The literature on the labor market impacts of forced migration is small compared to the corresponding literature in the "voluntary" migration context (Ruiz and Vargas-Silva, 2013). The lack of studies looking at forced migration is surprising given that forced migration situations often have certain features that enable the identification of causal relationships. One of the difficulties to identify causal relationships between immigration and host country labor markets is that migrants are attracted to those locations with positive economic trends. Several studies have avoided this problem by looking at situations in which political factors such as the independence of a country (e.g. Hunt, 1992) or the temporal/permanent disappearance of emigration restrictions in an otherwise restrictive regime (e.g. Card, 1990; Friedberg, 2001) are the main drivers of emigration. Violence is the main driver of emigration for forced migrants, an element which is often unrelated to the economic situation of the host location. In these situations forced migration leads to an 
exogenous shift in the labor supply of the host location (Calderon and Ibañez, 2009). However, forced migrants still have some degree of agency and, while they are forced to leave their homes in response to conflict, they may still be able to select their destination, providing a challenge to any claims of causal relationships. This paper looks at a situation in which the location of refugees was affected by a series of geographical factors and logistical decisions. These factors and decisions resulted in a natural experiment in which it is possible to explore the labor market impacts of forced migration.

Large ethnic conflicts erupted in Burundi and Rwanda during the early 1990s. In a short period of time, hundreds of thousands of people abandoned these two countries and moved to neighboring Tanzania in order to escape violence. The Kagera region in Tanzania, which borders both Burundi and Rwanda, was particularly affected by the inflow of refugees. However, refugees were not evenly distributed across the region. A series of natural topographic barriers (i.e. chain of mountains and game reserves), logistical decisions (i.e. authorities deciding to locate refugee camps close to the border) and, above all, distance from Burundi and Rwanda resulted in a much higher concentration of refugees in the western part of Kagera in comparison to the eastern part (Maystadt and Verwimp, 2014). In this article we make use of the Kagera Health and Development Survey (KHDS), a longitudinal dataset which contains information about Kagera residents before and after the refugee shock, to explore the implications of this shock for the labor market outcomes of Tanzanians.

This region has been the focus of analysis in previous studies. Some studies have used the 2004 round of the KHDS to compare to the pre-shock period and explore the impacts of refugees on health outcomes, poverty levels and well-being in general. Baez (2011) used a difference-in-difference approach to explore the impact of exposure to the refugee shock at a young age on health outcomes. He compared individuals on both sides of the geographical barrier. This approach has the benefit of not relying on imprecise estimates on the number of 
refugees in any given location and including urban refugees as well as those in camps. For robustness purposes, he also used distance to the border of Rwanda as a measure of the intensity of the refugee shock. The results from Baez (2011) linked children's exposure to the refugee shock in Kagera to a reduction of $7.1 \%$ in schooling and 7 percentage points in literacy rates. Maystadt and Verwimp (2014) rely on the distance of communities from refugee camps to explore the impact of forced migration on the host community consumption levels. The distance of communities from particular refugee camps is weighted by an estimate of the population of those refugee camps. They argue that the location of particular refugee camps was exogenous as it was based on cost decisions and facilitating the repatriation process later on. The key insight from Maystadt and Verwimp (2014) is that the refugee shock had a heterogeneous impact on natives. They find that agricultural workers in Kagera suffered the most from increased competition in labor markets, while self-employed farmers and non-agricultural workers benefited from the refugee inflow.

In this paper we use the first and last rounds of this survey (i.e. 1991 and 2010 rounds) to explore the long-term labor market impacts of forced migration. We use distance from the Burundian and Rwandan border, and distance from refugee camps for identification purposes. If, as argued by Maystadt and Verwimp (2014), the main activities of households determine the degree of the impact of the refugee shock on well-being, then we can expect the refugee shock to affect decisions regarding the choice of economic activity. This also follows from the research in the "voluntary" migration literature in developed countries which shows that immigration can affect both, wages within occupations and the allocation of natives across occupations (Ortega and Verdugo, 2011; Peri and Sparber, 2009). These impacts are likely to be present in the case of low income countries and in the forced migration context. However, the evidence of these impacts remains scarce. 
The degree to which refugees may affect the labor market outcomes of the host country natives depends on the degree of substitutability between refugees and natives. Evidence from previous forced migration situations suggests that there are situations in which refugees could be considered close substitutes for natives. For instance, Braun and Mahmoud (2014) explore the impact of forced migration of ethnic Germans from Eastern Europe to Germany after World War II. In this case, forced migrants and natives spoke the same language and had similar educational backgrounds. Unsurprisingly, they find an important negative effect of forced migration on native employment.

A significant degree of substitutability could be expected in the case of the Great Lakes region. Individuals in Burundi, Rwanda and Tanzania rely heavily on agricultural work for subsistence. The three countries also have low average educational levels. The net enrolment rate for primary school for Burundi in 1993 was 48\%, while it was 50\% for Tanzania (World Bank, 2014). ${ }^{1}$ There is also a language overlap between the three countries. Swahili, the official language of Tanzania, is commonly spoken in Burundi and Rwanda. These similarities suggest that refugees could in fact have an important impact on the Tanzanian labor market. Refugees are also in a more desperate situation and the evidence suggests that low-skilled refugees from Burundi and Rwanda were willing to accept a lower wage than low-skilled Tanzanian workers in order to do similar work (Maystadt and Verwimp, 2014). Moreover, it was common to just pay refugees with food instead of money (Lawrence and King, 1998). As such, we could expect Tanzanians to either move out or be displaced of those activities which could easily be done by refugees. In particular, given the importance of agricultural work for the region we would expect refugees to engage in agricultural work as employees and for Tanzanians to move to other activities that require more idiosyncratic and culture specific knowledge.

\footnotetext{
${ }^{1}$ Information not available for Rwanda.
} 
Tanzania also has a long history of casual labor (Dercon and Krishnan, 1996; Mbilinyi, 1986). Casual workers are typically hired on a daily basis to do basic jobs with low degrees of responsibility for which they receive a relatively low payment. An inflow of refugees willing to engage in casual labor for an even lower payment could lead to a substitution of casual native workers for casual refugee workers. Whitaker (2002) provides evidence that in some areas of Tanzania the wage of casual workers dropped by $50 \%$ after the refugee inflow. Moreover, casual labor wages varied depending on distance from the refugee camps. In camp areas, where there was now a large supply of causal labor, these workers earned significantly less than in other areas (Whitaker, 1999).

We have information on individuals collected during the September 30, 1991 - May 5, 1993 period (i.e. before the refugee shock) and in 2010 (about 17 to 19 years after the shock). Therefore, we can observe the long-term implications of the refugee shock on hosts' labor market outcomes. Using 2010 data also allows us to explore labor market outcomes of hosts after the "end" of the main refugee shock. Many of the refugees from Rwanda in Tanzania were repatriated during the late 1990s (Whitaker, 2003) and, as shown in Figure 1, refugees from Burundi in Tanzania have gradually returned home since 2001. The sudden spike in 2008 reflects the closing of several refugee camps by the Tanzanian Government during that year, including Lukole the last refugee camp in Kagera. Thousands of former Burundian refugees have also become naturalized Tanzanians (Fransen and Kuschminder, 2012).

[Figure 1]

\section{Background}

Burundi and Rwanda both experienced major conflicts in the early 1990s. These conflicts resulted in hundreds of thousands of casualties (Bundervoet, 2009; Daley, 2008; Kondylis, 2008; Martin and Hiddleston, 2006). Also, as a consequence of the conflicts, thousands were 
forced to flee their homes resulting in a large exodus of people moving to neighboring Tanzania. Over one million people sought refuge in Western Tanzania during the 1990s period and in some regions refugees outnumbered natives five to one (Whitaker, 2002). The outflow of refugees from Rwanda was concentrated mainly during the 1994-1996 period while in the case of Burundi, which experienced a longer conflict, there was a more gradual but steady outflow of refugees throughout the 1990s.

Kagera is a region of Tanzania that borders Burundi and Rwanda and was one of the main destinations of refugees in Tanzania due to its geographic location (see Figure 2). ${ }^{2}$ However, the refugees were not evenly spread across Kagera. As shown in Map A of Figure 3, a series of mountains separate east and west Kagera. Map B shows that there are also a series of natural reserves (mostly inhabited) that reinforce the geographical barrier between the two areas. These geographical characteristics, in addition to differences in the distance to the borders to Rwanda and Burundi, resulted in a natural experiment in which an area (i.e. West) was much more affected by the refugee inflow in comparison to the other area (i.e. East).

As explained by Maystadt and Verwimp (2014) the geographical barrier is not the only relevant factor. Based on costs and logistic considerations, the United Nations High Commission for Refugees and the Tanzanian Ministry for Home Affairs selected locations for refugee camps that were very close to the borders of Burundi and Rwanda. Transporting refugees to other locations in Tanzania would have required a major investment and repatriation was easier with locations close to the border.

\footnotetext{
${ }^{2}$ According to the 1988 Tanzanian Census, during the pre-shock period Kagera was home to $5.9 \%$ of the country's population whilst having $3.2 \%$ of the land of Tanzania (Planning Commission of Tanzania, 1998). Therefore, the pre-shock population density of Kagera (45.4 people per square kilometer) was slightly higher than the average of the rest of the country.
} 
[Figure 2]

[Figure 3]

\section{Conceptual framework}

\subsection{Immigration and native economic activities}

The evidence from the "voluntary" migration literature in developed countries suggests that an inflow of migrants may lead to a redistribution of natives across economic activities. For instance, Peri and Sparber (2009), using data for the USA, find that natives respond to immigration by changing occupations to those in which communication and culture specific knowledge plays a more important role. There is also evidence in the European context that natives move across occupations to those in which communication skills are more relevant in response to migration (e.g. D'Amuri and Peri 2014; Ortega and Verdugo, 2011).

The set of economic activities in which a person can get involved in Kagera is smaller than in the USA or Europe. However, even within this smaller set of activities there could be significant labor market consequences of refugee inflows. In fact, there is likely to be a large degree of substitutability for agricultural work outside of the household and casual waged work, activities that can be easily performed by refugees. There is less substitutability for non-agricultural work outside the household, which includes things such as government employment from which refugees are mostly excluded (Ruiz and Vargas-Silva, 2015).

The framework used by Peri and Sparber (2009) is based on the idea that immigration is associated with an increase in the marginal compensation in certain economic activities. It is possible to adjust this framework to the situation of refugee inflows in a low income country. The framework has a tradable consumption good $(Y)$ which is produced in a CES function by combining two non-tradable intermediate services: $Y_{L}$ and $Y_{H} . Y_{L}$ is produced by low-skilled workers, while $Y_{H}$ is produced by highly-skilled workers. 


$$
Y=\left[\beta Y_{L}^{\frac{\sigma-1}{\sigma}}+(1-\beta) Y_{H}^{\frac{\sigma-1}{\sigma}}\right]^{\frac{\sigma}{\sigma-1}}
$$

Where $\sigma$ if is the elasticity of substitution between $Y_{L}$ and $Y_{H}$. In the forced migration context it is natural to focus on $Y_{L}$ and it is assumed that two tasks are necessary to produce $Y_{L}$. These two tasks involve one general task $(G)$ which can be done easily by anyone including refugees and another task that requires a larger degree of idiosyncratic country and culture specific knowledge (C) in which natives have greater relative efficiency. Equation (2) gives the CES function for $Y_{L}$ :

$$
Y_{L}=\left[\beta_{L} G^{\frac{\theta_{L}-1}{\theta_{L}}}+\left(1-\beta_{L}\right) C^{\frac{\theta_{L}-1}{\theta_{L}}}\right]^{\frac{\theta_{L}}{\theta_{L}-1}}
$$

The key assumption is that natives are more proficient in doing the $\mathrm{C}$ task and that refugees supply a larger amount of $G$. An increase in the relative supply $G / C$ increases the compensation of $C$. As such, immigration is associated with an increase in the marginal compensation to $C$ tasks and with an increase in the supply of $C$ tasks by natives.

In the empirical section we explore how the refugee shock affected the economic activities of natives and pay particular attention to those areas in which there could be major differences in the degree of substitutability between refugees and natives (e.g. agricultural vs non-agricultural employment, casual work vs permanent work). We focus on the long-term consequences, i.e. 17 years after the arrival of the refugees and close to 2 years after the closure of the last refugee camp in Kagera. Individuals develop skills over time that relate to their specific economic activities and it could be relatively costly to change activities. There is also evidence that after the departure of the refugees many Tanzanians expected them to be back (i.e. renewed violence in Burundi and Rwanda) and that their choice of economic activities reflected those expectations (Whitaker, 1999). Overall, the presence of refugee 
camps may have transformed the host communities and these changes outlast the existence of these camps.

\subsection{The increase in demand for specific products and services}

The evidence from similar displacement situations suggests that the demand for specific products and services in the affected region is also influenced by the presence of refugees and employees of international organizations assisting with the crisis (Alix-Garcia et al., 2012). In Tanzania, the increase in population led to a major increase in the demand for new products which encouraged many enterprising natives to open up shops and to start different trade businesses (Whitaker, 2002). Natives have an advantage in establishing new businesses as they have more knowledge about the local practices and better access to key networks. That is, this activity relates strongly to the $\mathrm{C}$ tasks described in Equation (2). This could have led to a reallocation across economic activities on the part of natives and particularly to an increase in self-employment.

There was also a documented increase in demand for the production of aid-related goods, including different types of crops (Alix-Garcia and Saah, 2009). For instance, there is evidence of international agencies increasing the demand for wood and the price of tree farms (Whitaker, 1999). Therefore, it is possible for the natives mainly working on agriculture to remain in the same activity but to change the types of crops that they were cultivating. The possible diversification of crops may have long-term consequences. The evidence suggests that diversification of crops by households in Kagera relates strongly to a long-term improvement in economic conditions (De Weerdt, 2010). In the empirical section we also explore the impact of exposure to the refugee shock on the likelihood of being involved in non-farm self-employment and of changing types of crops.

\subsection{The transmission of human capital}


Finally, there could be different implications for the younger generations. The refugee shock could have affected the inter-generational transmission of human capital. This transmission may be disrupted by the refugee shock and the additional pressure on the country's scarce resources (e.g. schools). As mentioned above, Baez (2011) provided evidence of the impact of the refugee shock on human capital levels in Kagera. We dedicate an entire section of the analysis to explore the labor market consequences of the refugee shock for those who were of young age at the time of the shock.

\section{Methodology and data}

\subsection{Dataset}

The KHDS is a longitudinal dataset. The data was collected by the World Bank and contains detailed information on the labor market outcomes of individuals among many other variables. The KHDS has a very good tracking record over time. At least one member of the baseline household was re-interviewed in $89 \%$ of the cases in the 2010 round with $3 \%$ deceased and 8\% untraced (De Weerdt et al, 2012). The survey was initially conducted in 51 communities, but individuals were tracked over time even if they had move out of the community. The first round of the survey was conducted during the September 1991 - May 1993 period. The conflict in Burundi started in October 1993. Therefore, the first round of the survey precedes the start of the conflict.

Our main sample includes Tanzanians who were between sixteen and forty-six years of age in 1991, residing in Kagera and interviewed in both waves of the survey (panel). The top age limit for the first round is linked to the fact that we want individuals to still be of working age in the last round (with a top limit of 65 years of age). The residence restriction ensures that even if the individual moved from the base community there are no major differences in host location labor markets. For instance, many of those who left Kagera moved to the Dar es Salaam Region which has a more segmented labor market. We test the 
robustness of the results to these two conditions (i.e. residence restrictions and age limits) in Section 6.

The dependent variables reflect the activity choices of the individuals in the sample. First, we explore whether individuals are doing farming work (i.e. working in household shambas which are the plots of land used for growing crops) or livestock work (i.e. caring for household livestock), are in non-farm self-employment or are working for someone outside the household (i.e. employees) as their main activity. We focus on the main activity for the previous 12 months based on time use. In the first round of the survey there were questions about main activities during the previous seven days and previous twelve months. Initially the data was collected for the main activity during the previous seven days. If the individual had a different main activity during previous seven days and previous twelve months, then the information on the main activity during the previous 12 months was collected. In the 2010 round of the survey the respondent was only asked about activities for the previous 12 months and was asked to identify in which of the activities (if more than one) he/she spend the most time. Previous evidence for Tanzania (e.g. Beegle et al., 2012) suggests that different reference periods may affect the quality of the information (i.e. diminished capacity to remember). However, these studies focus on expenditures/consumption where there is a longer list of items to choose from. The impact of differences in the reference period should be less important in the case of main activities.

Second, we split employees between agricultural and non-agricultural employees. As mentioned above, we could expect the refugee shock to have a stronger impact on the likelihood of being an agricultural employee, a task that requires less culture specific knowledge. We also explore if the refugee shock had an impact on the number of activities the individual was doing (among the three activities) and if the forced migration shock resulted in changes in the types of crops the individual was cultivating. As explained above, 
one of the known consequences of refugee shocks is an increase in demand for different types of crops to service the refugee population and staff of international organizations. From the 2010 round of the survey we know the three main crops that the individual was cultivating and from the first round we know all crops the individual was cultivating before the arrival of refugees. Therefore, we can create a variable that indicates that the three main crops cultivated by the individual in 2010 were not crops that the individual cultivated during the first round of the survey.

Third, we explore the channels by which the refugee shock may be affecting economic activities. For this purpose we limit the analysis to the 2010 data and explore the role of wealth levels and casual labor in the pre-shock period. We include two variables from the first round of the survey to control for the economic background of the households. These variables are the total livestock owned by the household and the aggregate size in acres of the shambas of the household. In order to standardize the livestock across households we use Tropical Livestock Units (TLUs). Following Bundervoet (2009), we use the following units as weights: 1 cattle $=1$ TLU, 1 sheep $=0.17$ TLU, 1 goat $=0.17$ TLU, 1 pig $=0.25$ TLU and 1 rabbit or poultry $=0.01$ TLU. We use a question in which the respondent identifies his/her job as "temporary" in order to explore the role of casual labor. From those who had declared "employment for someone outside the household" as their main activity in the first round of the survey (i.e. employees in the pre-shock period), 52\% were in temporary jobs.

Finally, we extend the analysis to focus on labor market outcomes in 2010 for those Tanzanians who were less than 16 years of age in the 1991-1993 period (they must be included in both rounds of the survey). The study of these individuals provides interesting insights concerning the long-term impacts of forced migration for those who are affected at a very young age. We also present separate estimates for just those who were less than seven years of age in the first round. This very young cohort is much less likely to have had work 
experience before the refugee shock. The previous evidence suggests that it is likely that many of those 7 to 15 years of age during the pre-shock period were already involved in economic activities. Using data from the 2000/01 Household Budget Survey Kondylis and Manacorda (2012) estimate that $60 \%$ of children in Tanzania were working including $55 \%$ of children in ages 7 to 10 . In addition, using 1993 data (i.e. about the same time as the first round of the survey), Akabayashi and Psacharopoulos (1999) find that most children in ages 7 to 14 in the Tanga region of Tanzania worked.

\subsection{Identification}

We present results with different measures of the intensity of the refugee shock based on distance to the borders of Burundi, Rwanda and refugee camps during the first round of the survey. These intensity measures are the logarithm of the inverse of one of these distances. The inverse of the distance can be interpreted as the degree to which individuals were affected by refugee shock. Using the log decreases the effect of some communities being very close to the borders or camps. The distances are the Euclidian distance from the community of residence during the first round of the survey. Please note that for the first period (i.e. pre-shock) the intensity variable is set to zero.

We start by using the distance of the communities to the borders of Burundi and Rwanda separately. However, it is likely that a combination of the distance to the two countries better captures the intensity of the refugee shock. Geographical location is also likely to make the Rwandan border more relevant for northern districts of Kagera, while the opposite is true for southern districts. Northern Districts are: Kargawe, Bukoba and Muleba. Southern Districts are: Ngara and Biharamulo (see Figure 2). In order to account for this, we use an additional "weighted" measure that is given by (3) for communities $(c)$ in northern districts and by (4) for communities in southern districts. 


$$
\begin{aligned}
& \text { Shock North }_{c}=\log \left(\frac{1}{\rho\left(\text { distance Rwanda }_{c}\right)+(1-\rho)\left(\text { distance Burundi }_{c}\right)}\right) \\
& \text { Shock South }_{c}=\log \left(\frac{1}{(1-\rho)\left(\text { distance Rwanda }_{c}\right)+\rho\left(\text { distance Burundi }_{c}\right)}\right)
\end{aligned}
$$

Any value for $\rho$ above 0.5 and below 1 will give some importance to distance to both countries and put more weight on the distance to Rwanda for northern districts and the distance to Burundi for southern districts. We use $\rho=0.75$ for the main analysis of the paper. In the robustness section we show that the results are robust to using different values of $\rho$. Figure 4 shows the distribution of the "weighted" distances to Burundi and Rwanda across individuals in the sample. The mean distance is about 92 kilometers, but it varies from communities that were very close to the border ( 1 kilometer), to some that were about 150 kilometers away.

[Figure 4]

As an additional measure of the intensity of the refugee shock we use the distance from the community $(c)$ to the refugee camps $(r)$ : distance camp $p_{c, r}$. The presence of a camp can have major implications for labor markets. However, camps are only part of the picture. There was a significant presence of refugees in non-camp settings (often after spending some time in camps). Following Maystadt and Verwimp (2014) we weight the distance from each community to 13 different refugee camps by the population of each refugee camp. There are some necessary assumptions related to this measure.

First, camps had a changing population during the period of interest. In some instances the changes were quite significant for short periods of time and there were numerous transfers of refugees among camps. We selected the largest population estimate we could find on record for each refugee camp for the 1994-2008 period as the weight $\left(\operatorname{population}_{r}\right)$. 
Second, some camps were open for a short period of time (e.g. many were open during the 1994-1996 period), while others were functioning for over a decade (e.g. the Lukole camp closed in 2008). Moreover, some camps were re-opened after having being closed for some time. In order to adjust the analysis for this fact, we weighted each camp by an estimate of the number of years for which the camp was open during the 1994-2008 period (years $\left.{ }_{r}\right)$. Therefore, the equation that we used for the distance to the camps is:

$$
\text { Shock }_{c}=\log \left(\sum_{r=1}^{13}\left[\left(\frac{1}{\left(\text { distance camp }_{c, \mathrm{r}}\right)}\right)\left(\frac{\text { population }_{\mathrm{r}}}{\sum_{r=1}^{13} \text { population }_{\mathrm{r}}}\right)\left(\frac{\text { years }_{\mathrm{r}}}{14}\right)\right]\right)
$$

In order to make sure that distance was not capturing other differences between communities we estimated regressions between educational level in the first round of the survey (a proxy for economic background) and distance for each of the distance measures. We find no significant linear relationship between the variables.

Table 1 shows the relationship of the measures of economic activity with distance to the border. We separate individuals between those who were at below average distance from the border and those who were at above average distance from the border (using the weighted distance measure). The top portion of Table 1 provides statistics for all individuals doing a certain activity (e.g. for all those engaged in farming/livestock work). The bottom portion of Table 1 provides statistics using only the main activity based on time use (i.e. those doing two activities are only included in the activity to which they dedicated more time). There were many individuals doing farming/livestock work who were also employees or were in self-employment, but whose main activity was farming/livestock work. In the regressions we use the main activity of the individual.

During the pre-shock period there was a higher tendency for those who were more affected by the refugee shock to be doing farming/livestock work and this is also true for the 
last round. However, the gap between the two groups regarding farming/livestock work increased from eight percentage points in the pre-shock period to sixteen percentage points in the post-shock period. Self-employment was not important at the time of the first round and it was less common for those more affected by the refugee shock. As with the case for farming/livestock work, this difference is also present in the last round of the survey. Finally, there were no major differences in the likelihood of being an employee during the pre-shock period, but it is now substantially more common for those further away from the border.

[Table 1]

\subsection{Methodology}

The main estimations are a series of linear probability models along the following lines: ${ }^{3}$

$$
Y_{i t}=\beta_{0}+\beta_{1} \delta_{i}+\beta_{2} \lambda_{w}+\beta_{3} t+\beta_{4} I_{i t}+\beta_{5} X_{i t}+\varepsilon_{i t}
$$

Where $Y_{i t}$ is the binary outcome of interest for individual $i$ at time $t, \delta_{i}$ is the individual fixed effect, $\lambda_{w}$ are ward dummies ${ }^{4}, t$ is the time dummy $(2010=1), X_{i t}$ are a series of individual, household and district level controls and $\varepsilon_{i t}$ is the random error. $I_{i t}$ is the measure of the intensity of the refugee shock. Again, this measure is set to zero for the first period.

We present results with and without $X_{i t}$. We also present the main estimations using household of origin fixed effects instead of individual fixed effects. All estimations are reported with clustered standard errors based on the cluster of origin in the sample. The coefficient of interest for the analysis is $\beta_{4}$.

\footnotetext{
${ }^{3}$ We also considered the possibility of using a multinomial logit, but prefer the linear probability model because applying fixed effects was much more tractable and the estimates more reliable.
${ }^{4}$ Wards may be composed of several communities. An individual may move to a close by community within the same ward and the variable will not change.


The individual variables are standard in the literature and control for gender, marital status, age, education and household status. ${ }^{5}$ The household variables are also standard and control for gender and marital status of the household head, size of the household and child to adult ratio of the household. The district level controls include population of the district per square kilometer and the standard deviation of the daily precipitation of the location for the previous five years. An online appendix which accompanies this paper provides details of the construction of all the variables used in the estimations.

\section{Results}

\subsection{Main activity}

Table 2 provides the results for the case of main activities. The results suggest that the refugee shock had a positive impact on the likelihood of having farming /livestock work as the main economic activity. The result is consistent across the different measures of the intensity of the refugee shock.

On the other hand, the results suggest that the refugee shock did not affect the likelihood of having self-employment as the main economic activity. This is interesting in light of the substantial anecdotal evidence which suggest that Tanzanians were opening numerous shops and starting different businesses to service the needs of refugees and employees of international organizations (Whitaker, 2002). One possible explanation which follows from the previous literature is that much of the new small business activity was driven by Tanzanians moving from other regions of the country to Kagera (Maystadt and Verwimp, 2014). These "new" residents of Kagera are not included in our panel data.

\footnotetext{
${ }^{5}$ Since gender is time invariant, it is only included in the estimations which do not use the whole panel.
} 
The results also suggest that those who experienced a higher intensity of the refugee shock are less likely to work for someone outside the household as employees. Again, this result is consistent across the different measures of the intensity of the refugee shock.

To put the coefficient into context, using the "weighted" distance, the results suggests that increasing distance to the borders from 5 to 10 kilometers results in a 1.2 percentage points increase in the likelihood of having farming/livestock work as the main activity and a reduction of 0.9 percentage points in the likelihood of having work for someone outside the household as the main activity (i.e. being an employee).

[Table 2]

\subsection{Agricultural versus non-agricultural employment}

As explained above, the agricultural sector is particularly likely to be seriously impacted by the increase in the supply of low-skilled labor which resulted from the refugee shock. In the previous estimation agricultural and non-agricultural employees were both under the "employee" category. In Table 3 we provide separate estimates for the likelihood of being an agricultural and non-agricultural employee. The results suggest some impact on both sectors. However, the intensity measure that uses distance to camps, which could be regarded as the most direct measure of the refugee shock, is only significant for work as an agricultural employee.

[Table 3]

\subsection{Number of activities}

Another possibility is for the refugee shock to increase or decrease the number of activities in which an individual is involved. For instance, it is possible that the refugee shock has pushed those who were more affected towards diversification as a coping mechanism (e.g. working on household shambas and also working outside the household). On the other hand, it is also possible that those more affected have decided to specialize in particular activities and avoid 
those activities in which there is increasing competition from refugees. We explore these possibilities by creating a variable that reflects the number of activities in which the individual is involved ( 0 to 3 ) and use that variable as the dependent variable. In order to reflect the count data nature of the variable we also show results from a negative binomial regression. A significant and positive coefficient in this case would indicate that the refugee shock resulted in greater diversification of economic activities. Table 4 reports the results of this exercise. There is not much evidence of the refugee shock affecting the number of activities in which the person is involved.

[Table 4]

\subsection{Change in types of crops}

The results in Section 5.1 suggest that the refugee shock has a positive impact on having work in household shambas or caring for household livestock as the main activity. However, there could be differences in the nature of these activities, including differences in types of crops or livestock. In order to explore this we focus on the crops that the individual was cultivating during both rounds of the survey. In Table 5 we present results using 2010 data only and a dependent variable which indicates that the top three crops cultivated by the person in 2010 were not crops that the person cultivated during the first round of the survey. While this variable does not capture changes in crops perfectly, it does provide some insights regarding those changes.

As shown in the Table 5 there is not much evidence that the refugee shock has resulted in changes in the types of crops that are being cultivated. In order to explore these results further we exclude cooking bananas (e.g. plantains) from the list crops as the data suggest a considerable increase in this type of crop. Once we exclude cooking bananas there is some evidence which suggests that those more affected by the refugee shock have had a 
greater tendency to change types of crops. However, the result does not hold when we limit the analysis to those whose main activity was farming/livestock in 2010.

[Table 5]

\section{Refugees, previous characteristics and activities in 2010}

It is likely that the characteristics of individuals regarding economic activities and wealth levels in the pre-shock period have defined their employment transitions in the post-shock period. In this section we use the 2010 outcomes and see how those outcomes correlate with different pre-shock characteristics.

\subsection{Pre-shock economic background}

We include two variables from the first round of the survey to control for the economic background of the households. These variables are the total livestock owned by the household and the aggregate size in acres of the shambas of the household. The equation that we estimate for each indicator is:

$$
Y_{i}=\beta_{0}+\beta_{1} \delta_{i}+\beta_{2} \lambda_{w}+\beta_{3} A_{i}+\beta_{4} I_{i}+\beta_{5}\left(A_{i} * I_{i}\right)+\beta_{6} X_{i}+\varepsilon_{i}
$$

Where $A_{i}$ is the wealth indicator from the first period. We do not show the results of this estimation as results were insignificant for both the economic background variables and the interaction terms. We do not have evidence that the pre-shock economic background has played a major role on the impact of the shock on economic activities.

\subsection{Casual labor}

Temporary workers fall under the "employee" category in the previous estimations and could be driving the results regarding employees. As explained above, we expect casual workers to be particularly affected by the refugee shock as they were more likely to compete with refugees for jobs. In Table 6 we explore whether those who had temporary jobs in the 12 months prior to the first round of the survey were more or less likely to be in agricultural/livestock work, self-employment or being employees in 2010. We also include an 
interaction between the shock variable and temporary employment in 1991 . The equation that we estimate is:

$$
Y_{i}=\beta_{0}+\beta_{1} \delta_{i}+\beta_{2} \lambda_{w}+\beta_{3} T_{i}+\beta_{4} I_{i}+\beta_{5}\left(T_{i} * I_{i}\right)+\beta_{6} X_{i}+\varepsilon_{i}
$$

Where $T_{i}$ is a dummy that indicates that the person was a temporary worker in the pre-shock period. Table 6 shows the results for $T_{i}$ and the interaction term $\left(T_{i} * I_{i}\right)$.

The results suggest that being a temporary worker in the pre-shock period has a positive impact on the likelihood of being in self-employment in 2010. The interaction of temporary work and the intensity of the shock also has a positive impact on the likelihood of self-employment in 2010. On the other hand, the interaction between temporary work in the pre-shock period and the shock measure has a negative effect on the likelihood of being an employee in 2010. Hence, it seems that temporary work does matter for self-employment and the likelihood of being an employee in the future. In particular there could be a tendency for those who were more affected by the shock and were temporary workers during the pre-shock period to move from being employees to non-farm self-employment.

[Table 6]

As in the previous section, in Table 7 we separate those who are agricultural employees from other employees. The previous evidence suggested that the impact of the refugee shock on the likelihood of being an employee was largely the result of a decrease in the likelihood of being an agricultural employee. As shown in Table 7, temporary work in the pre-shock period seems to be more relevant for being a non-agricultural employee. Those who were temporary workers in the pre-shock period and were more affected by the shock are less likely to be non-agricultural employees in 2010 .

[Table 7]

\section{Younger cohort}


Until now the discussion has focused on individuals who were sixteen years of age or older during the first round of the survey. It is possible to argue that those Tanzanians who were very young at the time of the refugee shock are the ones who should be particularly affected in the long-term. As explained above, Baez (2011) found important human capital and health consequences for younger cohorts affected by the refugee shock. He hypothesizes that poor childhood health can disrupt human capital accumulation and affect labor market outcomes in adulthood, i.e. decrease the likelihood of doing jobs which require more human capital.

Results in Table 8 indicate that those children who were more affected by the refugee shock are more likely to be agricultural employees in adulthood. The evidence is stronger for those who were less than seven years of age at the time of the first round of the survey. We also conducted the analysis including an interaction between the shock intensity measure and the livestock of the household in 1991 (results not shown for space purposes). The interaction terms provide some evidence of the impact on the activities of children who were members of pre-shock wealthier households. There is evidence that those children from wealthier households who experienced greater exposure to the refugee shock are more likely to be employees in the future. They seem to be particularly more likely to be non-agricultural employees. Hence, while in general the refugee shock relates to a higher probability of agricultural employment, the shock results in a higher likelihood of being non-agricultural employees for those coming from wealthier households (i.e. pre-shock wealth).

[Table 8]

\section{Robustness}

\subsection{Placebo tests}


To explore the validity of our identification strategy we run a placebo test. ${ }^{6}$ The key assumption in the methodology is that in the absence of the refugee shock members of all communities would have followed a similar trajectory in terms of labor market outcomes. We use the fourth round of the KHDS to test this possibility. The fourth round of the KHDS was conducted during the June 6, 1993 - January 5, 1994 period, so it precedes the conflict in Rwanda although it coincides for a brief period with the Burundian conflict (which started on October 21, 1993). It is possible to argue that the main component of the refugee shock during the mid-1990s was displacement from Rwanda as displacement from Burundi increased gradually over a longer period. The short overlap with the Burundian conflict is unlikely to affect the labor market outcomes of residents of Kagera. Therefore, it is possible to conduct a placebo test by assigning the value of the variable measuring the intensity of the refugee shock to households in the fourth round of the survey when they should not have been affected by the shock (or affected to a much lesser degree than later on). The results indicate no significant impact of the refugee shock in any of the variables. In particular, there is no impact on the probability of doing farming/livestock or working for someone outside the household.

\subsection{Measure of distance}

In the estimations with the weighted distance measure a $75 \%(25 \%)$ weight was given to the distance to Rwanda for those districts in the north (south) of Kagera and a 25\% (75\%) weight was given to the distance to Burundi for those districts in the south (north). This is an arbitrary weight. Therefore, it is important to examine the robustness of the results to using different weights.

In order to do this we explore the results with different values of $\rho$ in Equations (3) and (4). In specific, we estimated regressions by increasing $\rho$ by 0.1 from 0 to 1 . For instance,

\footnotetext{
${ }^{6}$ The results of the robustness checks are not shown for space reasons, but are available from the authors upon request.
} 
if $\rho=1$ then only the distance to Rwanda matters for northern districts and only the distance to Burundi matters for southern districts. The contrary holds for $\rho=0$. The value $\rho=.75$ gives the results presented above. The results are very robust to changing the values of $\rho$.

\subsection{Moving outside of and within Kagera}

In the previous estimations we limited the sample to those individuals who were living in Kagera (not necessarily in the original community) during both rounds. This reduces potential differences in labor market opportunities across host locations. However, many of the individuals present in both rounds of the survey now live in other parts of Tanzania. Previous empirical evidence suggests that those who moved out of the communities of origin now have higher consumption levels. This is in part explained by a movement out of agricultural work (Beegle et al., 2011). The initial results are still robust to the inclusion of those individuals in the analysis (i.e. including those who moved to other regions).

It is also possible to argue that just moving within Kagera can affect the results. It may be that those more or less affected by the refugee shock have a greater tendency to move to urban areas in Kagera and that this explains the differences in activities. In order to shed some light on this we conducted an estimation excluding those individuals who did not reside in the community of origin during 2010 . The results are robust to excluding these individuals. 6.4 Age limits

The analysis only included those who were 65 years of age or younger in both rounds. We also tested the robustness of the results to relaxing this assumption. We include in the estimation all individuals 16 years of age and older who were present in both rounds of the sample. The results are broadly robust to this adjustment. The coefficients are smaller and less significant, but we only lose significance at the ten percent level for the intensity measure constructed with the distance to Rwanda.

\subsection{Geographical differences}


Another potential limitation of the analysis is that it includes many households that were originally located in communities in the Bukoba Urban district (about 1/5 of the original communities). The Bukoba Urban district has a higher population density and is the regional capital. The Bukoba Urban district is on the north-east side of Kagera, relatively far from Burundi and Rwanda, and particularly far from the border of the Ngara district with Burundi where many of the refugee camps were located. The geographical location of this district and its more urban nature (versus the rural nature of other districts) could be affecting the results. The results are overall consistent with our original estimates if we exclude individuals residing in the Bukoba Urban district. We only lose significance for the employee estimation in which the intensity measure is constructed with distance to camps. But even in that case the coefficient is still negative.

\subsection{Distance to Uganda}

It is also possible to argue that distance to Uganda is an important factor that is not controlled for in the previous estimations. Our treatment variables relate strongly to the east-west location of the individual during the pre-shock period, but it is possible to argue that the north-south location of the individual should also be controlled for as recovery after the conflict in Uganda has been known to be particularly strong in recent years (Hoeffler et al., 2011). As a robustness test we include distance to Uganda in the estimations along with the shock intensity measures. We include distance to Uganda in the same way that the shock measures are constructed (i.e. the log of the inverse of distance). The distance to Uganda is not statistically significant in any of the estimations. For the most part the results are robust to including distance to Uganda in the estimations. We lose significance for the likelihood of doing farming/livestock work for the estimation using distance to camps, but even in that case the coefficient is positive and very close to being significant at the $10 \%$ level (i.e. $t=$ $1.63)$. 


\subsection{Potential spatial correlation between villages}

Finally, it is important to check for potential spatial correlation between villages in the computation of the standard errors. For this purpose we use distance among the villages and estimate a spatial fixed effects model. We assume that there are no spatial effects after 50 kilometers, but the results are robust to changing this assumption regarding the range of the impacts. The main results are fully robust to using this model.

\section{Conclusion}

There is a large literature on the impact of "voluntary" migration in host countries labor markets. Most of the literature focuses on economic migrants who move for employment reasons and there is a scarcity of evidence on the labor market impacts of forced migrants. This is a worrying omission because forced migration affects millions of people around the world and the large majority of refugees worldwide are in developing countries with limited resources. Therefore, the implications of forced migration for economic development and growth could be significant for both, host and home countries. In addition, the design and implementation of humanitarian assistance and development programs requires a good understanding of labor market dynamics of affected populations.

In this paper we explore the labor market consequences of forced migration to Tanzania, a country that has been a major host of refugees for several decades. Our results show multiple impacts of a refugee shock on the labor market outcomes of Tanzanians, including impacts on the likelihood of working on farming/livestock for subsistence and the probability of working for someone outside the household. In particular, the refugee shock resulted in Tanzanians having a higher likelihood of working in household shambas or caring for household livestock and a lower likelihood of working outside the household as employees. They were particularly less likely to be agricultural employees, suggesting a possible substitution effect between refugees and natives in this activity. Also, many of the 
natives who were casual workers before the shock changed to other activities, including selfemployment in the post-shock period. These casual workers were particularly likely to have competed with refugees for jobs. These results are, in general, consistent with the evidence from the "voluntary" migration literature in developed countries which suggests that natives adjust to immigration flows by changing economic activities. This is an important finding because there is scarce evidence on this type of adjustment by the native population in the context of a host low income country.

The ability to work is often the most valuable asset of individuals in low income countries. As our results show, a refugee shock can impact host country labor markets and the choice of economic activity of the host population. Labor market impacts should be a key consideration of humanitarian institutions and national governments when dealing with a forced displacement episode and when developing policies to respond to such episode. Particular emphasis could be placed on the wellbeing of those native workers who are likely to compete directly with refugees in the labor market, such as agricultural and/or casual waged workers. 


\section{References}

Akabayashi, H. and Psacharopoulos, G. (1999). The trade-off between child labour and human capital formation: A Tanzanian case study. The Journal of Development Studies, 35, pp. 120-140.

Alix-Garcia, J., Bartlett, A. and Saah, D. (2012) Displaced populations, humanitarian assistance and hosts: a framework for analyzing impacts on semi-urban households. World Development, 40, pp. 373-386.

Alix-Garcia, J. and Saah, D. (2009) The effect of refugee inflows on host communities: evidence from Tanzania. The World Bank Economic Review, 24, pp. 148-170.

Baez, J. (2011) Civil wars beyond their borders: the human capital and health consequences of hosting refugees. Journal of Development Economics, 96, pp. 391-408.

Beegle, K., De Weerdt, J., and Dercon, S. (2011) Migration and economic mobility in Tanzania: Evidence from a tracking survey. Review of Economics and Statistics, 93, pp. $1010-1033$

Beegle, K., De Weerdt, J., Friedman, J. and Gibson, J. (2012) Methods of household consumption measurement through surveys: Experimental results from Tanzania. Journal of Development Economics, 98, pp. 3-18.

Borjas, G.J. (1994) The economics of immigration. Journal of Economic Literature, 32, pp. $1667-1717$

Borjas, G.J. (2003) The labor demand curve is downward sloping: Reexamining the impact of immigration on the labor market. The Quarterly Journal of Economics, 118, pp. 1335-1374.

Braun, S. and Mahmoud, T.O. (2014) The employment effects of immigration: evidence from the mass arrival of German expellees in post-war Germany. The Journal of Economic History, 74, pp. 69-108. 
Bundervoet, T. (2009) Livestock, land and political power: The 1993 killings in Burundi. Journal of Peace Research, 46, pp. 357-376.

Calderon, V. and Ibañez, A.M. (2009) Labor market effects of migration-related supply shocks: evidence from internally displaced populations in Colombia. Research Working Paper, No. 14, MICROCON.

Card, D. (1990) The impact of the Mariel Boatlift on the Miami labor market. Industrial and Labor Relations Review, 43, pp. 245-257.

Daley, P. (2008) Gender and Genocide in Burundi: The Search for Spaces of Peace in the Great Lakes Region. Oxford: James Currey, Bloomington, Indiana: Indiana University Press. D'Amuri, F. and Peri, G. (2014) Immigration, jobs, and employment protection: evidence from Europe before and during the great recession. Journal of the European Economic Association, 12, pp. 432-464.

Dercon, S. and Krishnan, P. (1996) Income portfolios in rural Ethiopia and Tanzania: Choices and constraints. The Journal of Development Studies, 6, pp. 850-875.

De Weerdt, J. (2010) Moving out of poverty in Tanzania: Evidence from Kagera. The Journal of Development Studies, 46, pp. 331-349.

De Weerdt, J., Beegle, K., Lilleør, H.B., Dercon, S., Hirvonen, K., Kirchberger, M. and Krutikova, S. (2012) Kagera Health and Development Survey 2010: Basic Information Document. Rockwool Foundation Working Paper Series, Study Paper No. 46.

Dustmann, C., Fabbri, F. and Preston, I. (2005) The impact of immigration on the British labour market. The Economic Journal, 115, F324-F341.

Dustmann, C., Frattini, T. and Preston, I. (2013) The effect of immigration along the distribution of wages. Review of Economic Studies, 80, pp. 145-173. 
Fransen, S. and Kuschminder, K. (2012) Back to the land: The long-term challenges of refugee return and reintegration in Burundi. New Issues in Refugee Research, Research Paper No.242.

Friedberg, R.M. (2001) The impact of mass migration on the Israeli labor market. The Quarterly Journal of Economics, 116, pp. 1373-1408.

Hunt, J. (1992) The impact of the 1962 repatriates from Algeria on the French labor market. Industrial and Labor Relations Review, 45, pp. 556-572.

Hoeffler, A., Ijaz, Shahbano, S. and von Billerbeck, S. (2011) Post-conflict recovery and peacebuilding. Washington, DC: World Bank.

Kerr, S.P. and Kerr, W.R. (2011) Economic impacts of immigration: A survey. Finnish Economic Papers, 24, pp. 1-32.

Kondylis, F. (2008) Agricultural outputs and conflict displacement: evidence from a policy intervention in Rwanda. Economic Development and Cultural Change, 57, pp. 31-66.

Kondylis, F. and Manacorda, M. (2012) School proximity and child labor evidence from rural Tanzania. Journal of Human Resources, 47, pp. 32-63.

Lawrence, M. and King, A. (1998) "Household food economy assessment of Burundian refugees in Northwest Tanzania", undertaked jointly by Save the Children Fund (UK), World Food Programme-Tanzania and UNHCR Tanzania.

Martin, S. and Hiddleston, T. (2006) "Burundi: A Case of Humanitarian Neglect" Chapter 2 in Eds. N. Van Hear and C. McDowell, Catching Fire: Containing Forced Migration in a Volatile World. Lexington Books: Lanham, Maryland.

Maystadt, J. and Verwimp, P. (2014) Winners and losers among a refugee-hosting population. Economic Development and Cultural Change, 62, pp. 769-809.

Mbilinyi, M. (1986) Agribusiness and casual labor in Tanzania. African Economic History, 15, pp. $107-141$. 
Ortega, J. and Verdugo, G. (2011) Immigration and the occupational choice of natives: A factor proportions approach. Discussion Paper, No. 5451, IZA.

Peri, G. and Sparber, C. (2009) Task specialization, immigration, and wages. American Economic Journal: Applied Economics, 1, 3, pp. 135-69

Planning Commission of Tanzania (1998) Kagera region socio-economic profile. Dar es Salaam: Planning Commission.

Ruiz, I. and Vargas-Silva, C. (2013) The economics of forced migration. Journal of Development Studies, 49, pp. 772-784.

Ruiz, I. and Vargas-Silva, C. (2015) The labor market impacts of forced migration. American Economic Review, forthcoming.

United Nations High Commission for Refugees (2012). Global Report 2012. New York: UNHCR.

United Nations High Commission for Refugees (2014). UNHCR Statistical Online Population Database, United Nations High Commissioner for Refugees (UNHCR), Data extracted: 05/09/2014: www.unhcr.org/statistics/populationdatabase.

United Nations Population Division (2013). Trends in International Migrant Stock: The 2013 Revision. New York: UNPD.

Whitaker, B.E. (1999) Changing opportunities: Refugees and Host Communities in Western Tanzania. New Issues in Refugee Research, 11.

Whitaker, B.E. (2002) Refugees in Western Tanzania: The distribution of burdens and benefits among local hosts. Journal of Refugee Studies, 15, pp. 339-358.

Whitaker, B.E. (2003) "Changing Priorities in Refugee Protection: The Rwandan Repatriation from Tanzania" Chapter 8 in Eds. G. Loescher, M. Gibney and N. Steiner, Problems of Protection: UNHCR and the Protection of Refugees and Human Rights. Routledge: New York. 
Word Bank (2014). World Bank Development Indicators. Data extracted: 07/10/2014: http://data.worldbank.org/data-catalog/world-development-indicators 
Figure 1 - Refugee returnees from Tanzania to Burundi

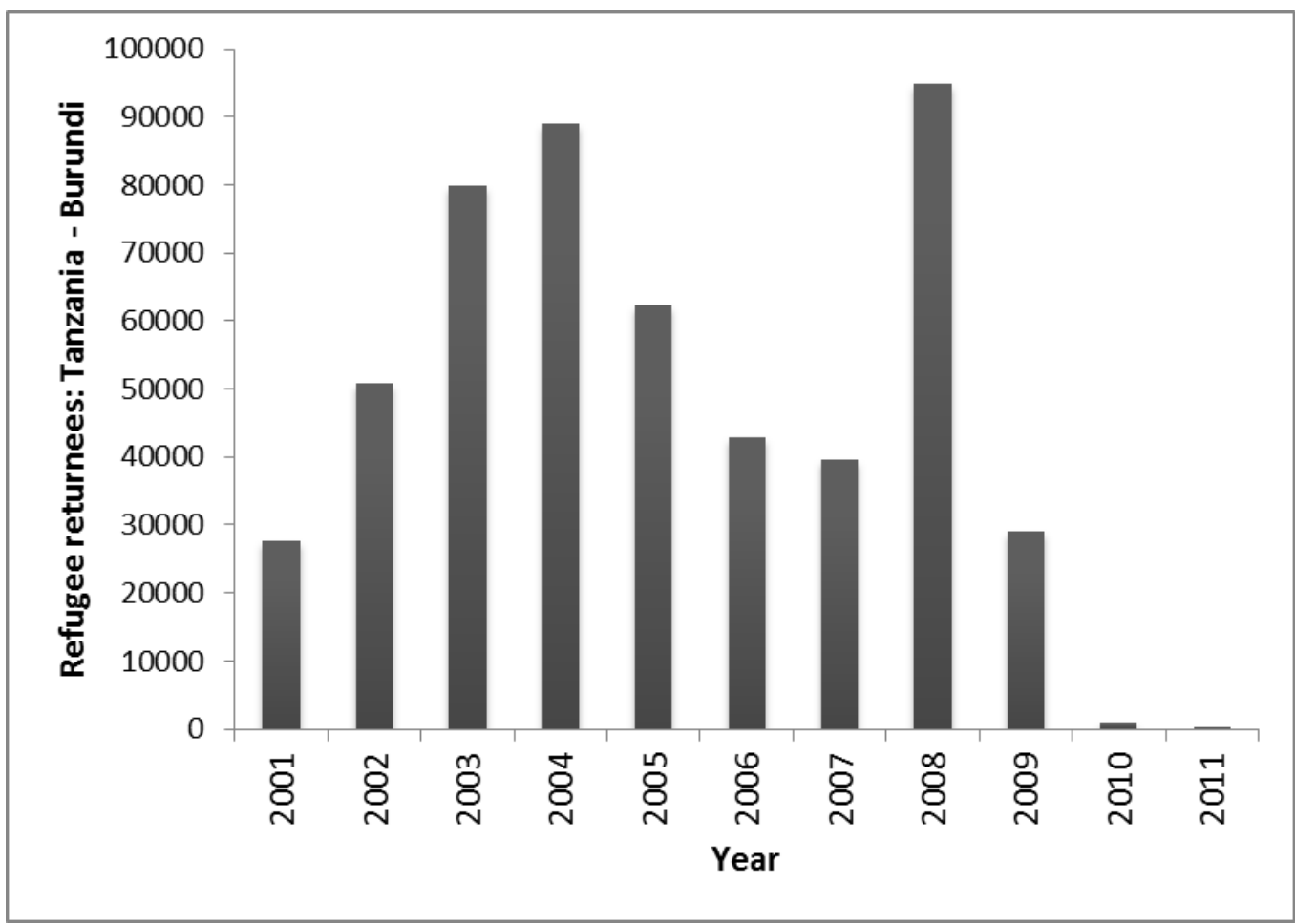

Note: data source is UNHCR (2014). The last refugee camp in Kagera closed in 2008. 
Figure 2 - Maps of Tanzania (A) and Kagera (B)

(A)

Tanzania



(B)

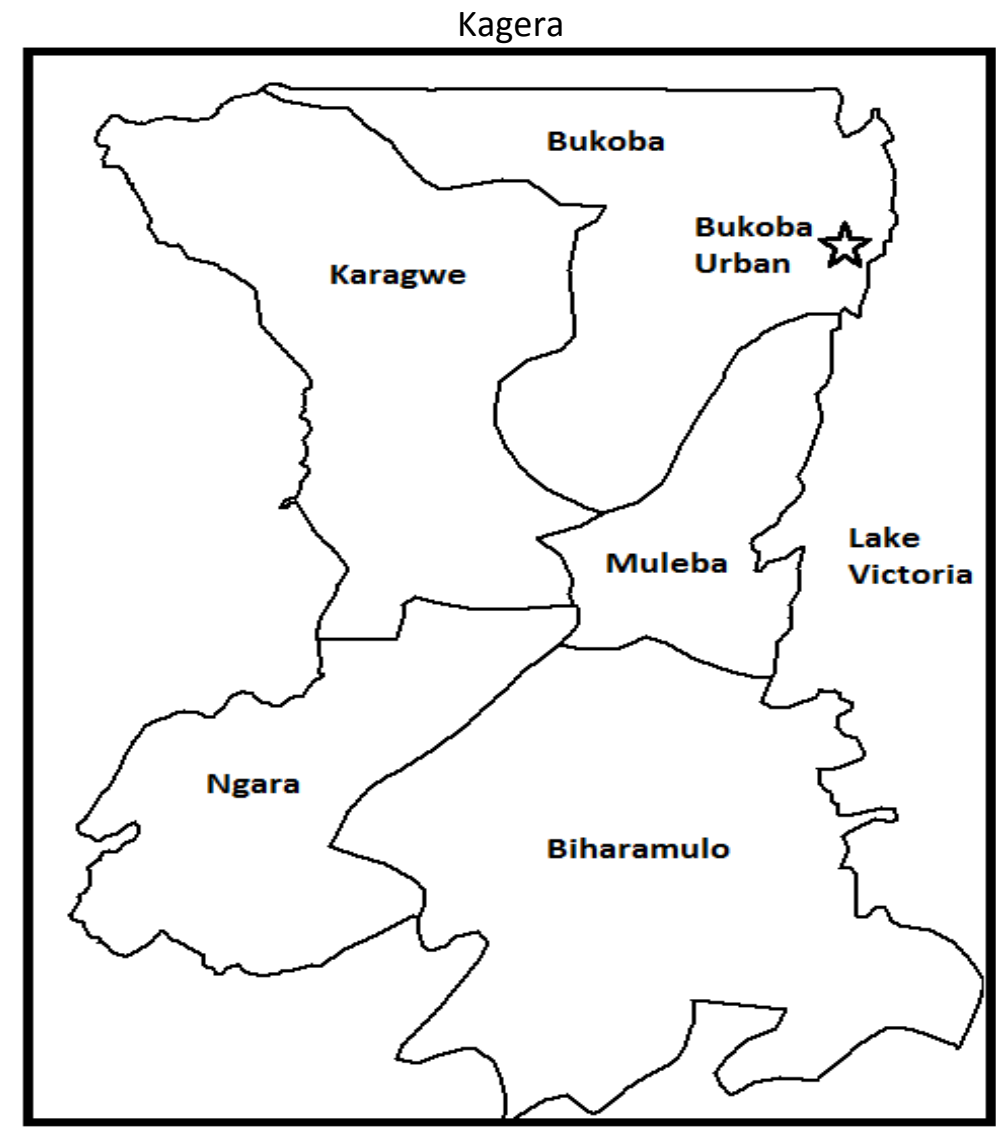


Figure 3 - Topographic (A) and vegetation/protected areas (B) maps of Kagera.

(A)



(B)

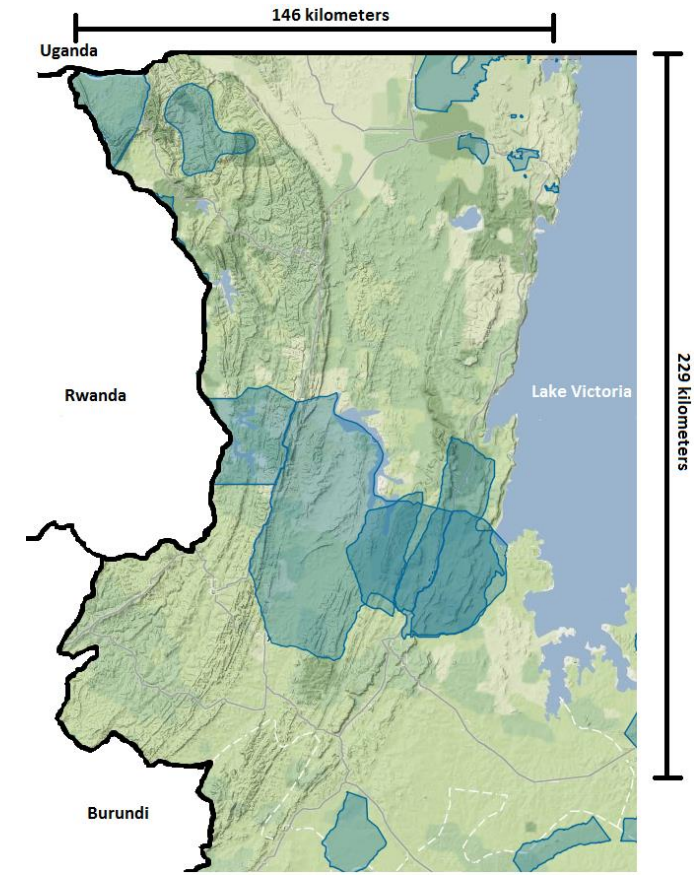

Note: Information on the location of protected areas comes from the World Database on Protected Areas (WDPA). The areas with green shades superimposed are protected areas, in most cases these are game reserves. 
Figure 4 - Distribution of "weighted" distances to the borders of Burundi and Rwanda.

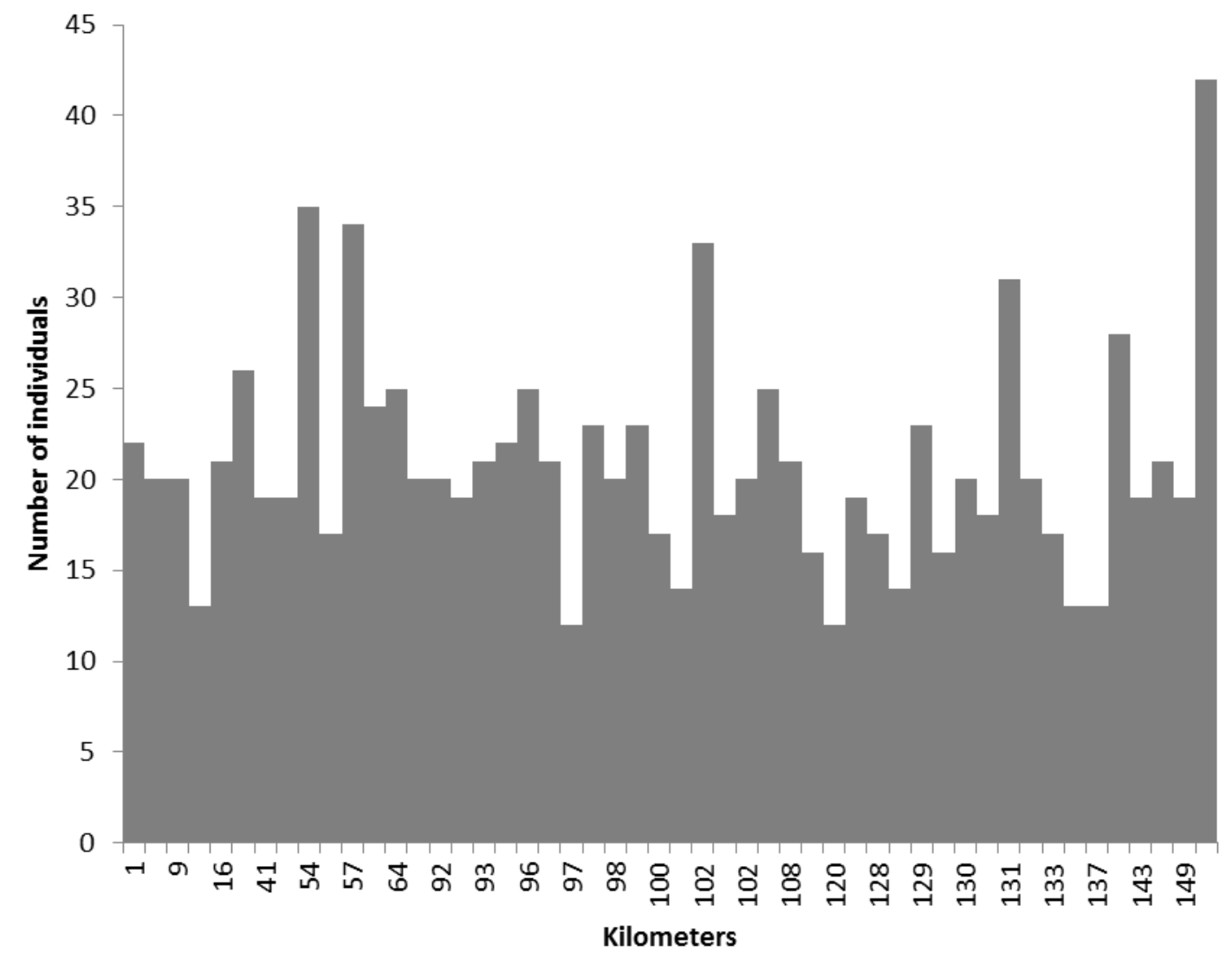


Table 1 - Descriptive statistics of economic activities.

\begin{tabular}{|c|c|c|c|c|}
\hline \multirow[b]{3}{*}{ Activity } & \multicolumn{2}{|c|}{1991} & \multicolumn{2}{|c|}{2010} \\
\hline & \multicolumn{4}{|c|}{ Distance to the border } \\
\hline & $\begin{array}{l}\text { Below } \\
\text { mean }\end{array}$ & $\begin{array}{c}\text { Above } \\
\text { mean }\end{array}$ & $\begin{array}{l}\text { Below } \\
\text { mean }\end{array}$ & $\begin{array}{c}\text { Above } \\
\text { mean }\end{array}$ \\
\hline & \multicolumn{4}{|c|}{ (A) All } \\
\hline Farming/livestock work & $96.5 \%$ & $92.8 \%$ & $93.7 \%$ & $90.4 \%$ \\
\hline Self-employment (non-farm) & $10.1 \%$ & $18.8 \%$ & $32.4 \%$ & $38.0 \%$ \\
\hline \multirow[t]{2}{*}{ Employee } & $24.4 \%$ & $21.9 \%$ & $26.0 \%$ & $39.1 \%$ \\
\hline & \multicolumn{4}{|c|}{ (B) Main activity only } \\
\hline Farming/livestock work & $87.9 \%$ & $80.0 \%$ & $80.0 \%$ & $63.6 \%$ \\
\hline Self-employment (non-farm) & $0.01 \%$ & $6.7 \%$ & $9.2 \%$ & $15.9 \%$ \\
\hline Employee & $9.2 \%$ & $10.7 \%$ & $9.5 \%$ & $18.3 \%$ \\
\hline None & $2.9 \%$ & $2.6 \%$ & $1.3 \%$ & $2.2 \%$ \\
\hline Observations & 315 & 690 & 315 & 690 \\
\hline
\end{tabular}

Notes: The weighted distance measure is used to split the observations. This distance measure gives a weight of $0.75(0.25)$ to distance to Burundi (Rwanda) and a weight of $0.25(0.75)$ to distance to Rwanda (Burundi) for those residing in Southern (Northern) Districts of Kagera. Main activities are based on time use. 
Table 2 - Regression results for main economic activities.

\begin{tabular}{|c|c|c|c|c|c|c|c|c|}
\hline \multirow[t]{2}{*}{ Dependent variable } & \multicolumn{8}{|c|}{ Intensity of the forced migration shock (i.e. $\log (1 /$ distance $)$ constructed with distance to: } \\
\hline & \multicolumn{2}{|c|}{ Burundi } & \multicolumn{2}{|c|}{ Rwanda } & \multicolumn{2}{|c|}{ Weighted } & \multicolumn{2}{|c|}{ Camps } \\
\hline & & & & Using indivi & ual fixed effe & & & \\
\hline Farming/livestock & $\begin{array}{c}0.04 \\
(4.44)^{* * *}\end{array}$ & $\begin{array}{c}0.03 \\
(3.08)^{* * *}\end{array}$ & $\begin{array}{c}0.04 \\
(3.67)^{* * *}\end{array}$ & $\begin{array}{c}0.04 \\
(2.79)^{* * *}\end{array}$ & $\begin{array}{c}0.05 \\
(4.03)^{* * *}\end{array}$ & $\begin{array}{c}0.04 \\
(2.94)^{* * *}\end{array}$ & $\begin{array}{c}0.06 \\
(2.87)^{* * *}\end{array}$ & $\begin{array}{c}0.05 \\
(2.12)^{* *}\end{array}$ \\
\hline Self-employment & $\begin{array}{c}-0.01 \\
(-1.35)\end{array}$ & $\begin{array}{l}-0.00 \\
(-0.40)\end{array}$ & $\begin{array}{c}-0.01 \\
(-1.06)\end{array}$ & $\begin{array}{c}-0.00 \\
(-0.35)\end{array}$ & $\begin{array}{c}-0.01 \\
(-1.22)\end{array}$ & $\begin{array}{l}-0.00 \\
(-0.38)\end{array}$ & $\begin{array}{c}-0.02 \\
(-1.15)\end{array}$ & $\begin{array}{l}-0.01 \\
(-0.28)\end{array}$ \\
\hline Employee & $\begin{array}{c}-0.03 \\
(-3.89)^{* * *}\end{array}$ & $\begin{array}{c}-0.03 \\
(-3.21)^{* * *}\end{array}$ & $\begin{array}{c}-0.03 \\
(-4.03)^{* * *} \\
\text { (B) Usi }\end{array}$ & $\begin{array}{c}-0.03 \\
(-3.39)^{* * *} \\
\text { g household }\end{array}$ & $\begin{array}{c}-0.03 \\
(-4.65)^{* * *} \\
\text { forigin fixe }\end{array}$ & $\begin{array}{l}-0.03 \\
(-3.57)^{* * *} \\
\text { effects }\end{array}$ & $\begin{array}{c}-0.04 \\
(-2.50)^{* *}\end{array}$ & $\begin{array}{c}-0.03 \\
(-2.01)^{* *}\end{array}$ \\
\hline Farming/livestock & $\begin{array}{c}0.04 \\
(3.76)^{* * *}\end{array}$ & $\begin{array}{c}0.03 \\
(2.82)^{* * *}\end{array}$ & $\begin{array}{c}0.04 \\
(3.02)^{* * *}\end{array}$ & $\begin{array}{c}0.03 \\
(2.40)^{* *}\end{array}$ & $\begin{array}{c}0.04 \\
(3.30)^{* * *}\end{array}$ & $\begin{array}{c}0.04 \\
(2.56)^{* *}\end{array}$ & $\begin{array}{c}0.06 \\
(3.06)^{* * *}\end{array}$ & $\begin{array}{c}0.05 \\
(2.28)^{* *}\end{array}$ \\
\hline Self-employment & $\begin{array}{l}-0.01 \\
(-1.35)\end{array}$ & $\begin{array}{l}-0.00 \\
(-0.40)\end{array}$ & $\begin{array}{l}-0.01 \\
(-1.00)\end{array}$ & $\begin{array}{l}-0.00 \\
(-0.22)\end{array}$ & $\begin{array}{l}-0.01 \\
(-1.19)\end{array}$ & $\begin{array}{l}-0.00 \\
(-0.31)\end{array}$ & $\begin{array}{l}-0.02 \\
(-1.21)\end{array}$ & $\begin{array}{l}-0.01 \\
(-0.29)\end{array}$ \\
\hline Employee & $\begin{array}{c}-0.03 \\
(-4.03)^{* * *}\end{array}$ & $\begin{array}{c}-0.03 \\
(-3.44)^{* * *}\end{array}$ & $\begin{array}{c}-0.03 \\
(-4.06)^{* * *}\end{array}$ & $\begin{array}{c}-0.03 \\
(-3.49)^{* * *}\end{array}$ & $\begin{array}{c}-0.03 \\
(-4.35)^{* * *}\end{array}$ & $\begin{array}{c}-0.03 \\
(-3.71)^{* * *}\end{array}$ & $\begin{array}{c}-0.04 \\
(-2.92)^{* * *}\end{array}$ & $\begin{array}{c}-0.03 \\
(-2.39)^{* *}\end{array}$ \\
\hline $\begin{array}{l}\text { Observations } \\
\text { Controls }\end{array}$ & 2,010 & $\begin{array}{c}2,010 \\
\boldsymbol{V}\end{array}$ & 2,010 & $\begin{array}{c}2,010 \\
\boldsymbol{V}\end{array}$ & 2,010 & $\begin{array}{c}2,010 \\
\boldsymbol{V}\end{array}$ & 2,010 & $\begin{array}{c}2,010 \\
\boldsymbol{V}\end{array}$ \\
\hline
\end{tabular}

Notes: The dependent variables reflect the main activity choices of the individuals in the sample: working in household shambas/livestock, non-farm self-employment or working for someone outside the household. All coefficients come from separate estimations and are the coefficients for the measure of the intensity of the forced migration shock in a linear probability model. $t$-statistics are reported in parenthesis. ${ }^{* * *}$ indicates significant at $1 \%$ level, ${ }^{* *}$ indicates significant at $5 \%$ level, * indicates significant at $10 \%$ level. 
Table 3 - Regression results for agricultural versus non-agricultural employees.

\begin{tabular}{|c|c|c|c|c|c|c|c|c|}
\hline \multirow{3}{*}{$\begin{array}{l}\text { Dependent variable } \\
\text { Agricultural employee }\end{array}$} & \multicolumn{8}{|c|}{ Intensity of the forced migration shock (i.e. $\log (1 /$ distance $)$ ) constructed with distance to: } \\
\hline & \multicolumn{2}{|c|}{ Burundi } & \multicolumn{2}{|c|}{ Rwanda } & \multicolumn{2}{|c|}{ Weighted } & \multicolumn{2}{|c|}{ Camps } \\
\hline & $\begin{array}{c}-0.01 \\
(-1.65)^{*}\end{array}$ & $\begin{array}{c}-0.01 \\
(-1.73)^{*}\end{array}$ & $\begin{array}{c}-0.02 \\
(-1.76)^{*}\end{array}$ & $\begin{array}{c}-0.01 \\
(-1.47)\end{array}$ & $\begin{array}{c}-0.02 \\
(-1.69)^{*}\end{array}$ & $\begin{array}{c}-0.01 \\
(-1.57)\end{array}$ & $\begin{array}{c}-0.02 \\
(-2.40)^{* *}\end{array}$ & $\begin{array}{c}-0.02 \\
(-2.29)^{* *}\end{array}$ \\
\hline Non-agricultural employee & $\begin{array}{c}-0.02 \\
(-2.49)^{* *}\end{array}$ & $\begin{array}{l}-0.01 \\
(-1.62)\end{array}$ & $\begin{array}{l}-0.02 \\
(-1.56)\end{array}$ & $\begin{array}{l}-0.01 \\
(-1.47)\end{array}$ & $\begin{array}{c}-0.02 \\
(-2.35)^{* *}\end{array}$ & $\begin{array}{c}-0.01 \\
(-1.73)^{*}\end{array}$ & $\begin{array}{c}-0.02 \\
(-1.17)\end{array}$ & $\begin{array}{l}-0.01 \\
(-0.64)\end{array}$ \\
\hline Observations & 2,010 & 2,010 & 2,010 & 2,010 & 2,010 & 2,010 & 2,010 & 2,010 \\
\hline Controls & & $\checkmark$ & & $\checkmark$ & & $v$ & & $\checkmark$ \\
\hline
\end{tabular}

Notes: The dependent variables reflect the type of employment (agricultural, non-agricultural) of those who have employment outside the household as their main economic activity. All coefficients come from separate estimations and are the coefficients for the measure of the intensity of the forced

migration shock in a linear probability model. t-statistics are reported in parenthesis. ${ }^{* * *}$ indicates significant at $1 \%$ level, $* *$ indicates significant at $5 \%$ level, * indicates significant at $10 \%$ level. 
Table 4 - Impact on number of economic activities

\begin{tabular}{lcccccccc}
\hline & \multicolumn{3}{c}{ Intensity of the forced migration shock (i.e. log(1/distance)) constructed with distance to: } \\
Dependent variable & \multicolumn{2}{c}{ Burundi } & \multicolumn{2}{c}{ Rwanda } & Weighted & \multicolumn{2}{c}{ Camps } \\
\hline Number of activities & -0.04 & -0.03 & -0.02 & -0.02 & -0.03 & -0.03 & -0.02 & -0.02 \\
(0 to 3) & $(-1.31)$ & $(-1.89)^{*}$ & $(-0.63)$ & $(-1.18)$ & $(-1.14)$ & $(-1.78)^{*}$ & $(-0.24)$ & $(-0.43)$ \\
Observations & 2,010 & 2,010 & 2,010 & 2,010 & 2,010 & 2,010 & 2,010 & 2,010 \\
Controls & $\mathbf{V}$ & $\mathbf{V}$ & $\mathbf{V}$ & $\mathbf{V}$ & $\mathbf{V}$ & $\mathbf{V}$ & $\mathbf{V}$ & $\mathbf{V}$ \\
OLS FE & $\mathbf{V}$ & & $\mathbf{V}$ & & $\mathbf{V}$ & & $\mathbf{V}$ &
\end{tabular}

Negative binomial

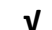
$\checkmark$ $\mathbf{v}$ $\sqrt{ }$

Notes: The dependent variable reflects the number of activities in which the individual is involved (among faming/livestock, self-employment and employee). The variable goes from zero (no activity) to three (all activities). All coefficients come from separate estimations and are the coefficients for the measure of the intensity of the forced migration shock. t-statistics are reported in parenthesis. ${ }^{* * *}$ indicates significant at $1 \%$ level, ${ }^{* *}$ indicates significant at $5 \%$ level, * indicates significant at $10 \%$ level. 
Table 5 - Regression results for changes in types of crops.

\begin{tabular}{|c|c|c|c|c|c|c|c|c|}
\hline \multirow[b]{2}{*}{ Dependent variable } & \multicolumn{8}{|c|}{ Intensity of the forced migration shock (i.e. $\log (1 /$ distance)) constructed with distance to: } \\
\hline & \multirow{2}{*}{\multicolumn{2}{|c|}{ Burundi }} & \multirow{2}{*}{\multicolumn{2}{|c|}{ Rwanda }} & \multirow{2}{*}{\multicolumn{2}{|c|}{ Weighted }} & \multirow{2}{*}{\multicolumn{2}{|c|}{ Camps }} \\
\hline & & & & & & & & \\
\hline \multirow[t]{2}{*}{ Different 2010 crops, all crops } & 0.03 & 0.04 & 0.03 & 0.04 & 0.03 & 0.04 & -0.07 & -0.05 \\
\hline & $(0.82)$ & $(1.16)$ & $(1.13)$ & $(1.40)$ & $(0.95)$ & $(1.26)$ & $(-0.57)$ & $(-0.38)$ \\
\hline \multirow[t]{2}{*}{ Different 2010 crops, no bananas } & 0.07 & 0.09 & 0.07 & 0.08 & 0.07 & 0.08 & -0.12 & -0.08 \\
\hline & $(1.63)$ & $(1.96)^{* *}$ & $(1.86)^{*}$ & $(2.13)^{* *}$ & $(1.87)^{*}$ & $(2.18)^{* *}$ & $(-0.90)$ & $(-0.57)$ \\
\hline \multirow[t]{2}{*}{ Observations } & 1,005 & 1,005 & 1,005 & 1,005 & 1,005 & 1,005 & 1,005 & 1,005 \\
\hline & \multicolumn{8}{|c|}{ (B) Only those whose main activity was farming/livestock in 2010} \\
\hline \multirow[t]{2}{*}{ Different 2010 crops, all crops } & 0.04 & 0.05 & 0.04 & 0.06 & 0.04 & 0.05 & 0.06 & 0.08 \\
\hline & $(0.80)$ & $(0.97)$ & $(1.04)$ & $(1.36)$ & $(1.04)$ & $(1.22)$ & $(0.56)$ & $(0.69)$ \\
\hline \multirow[t]{2}{*}{ Different 2010 crops, no bananas } & 0.05 & 0.07 & 0.05 & 0.07 & 0.06 & 0.08 & 0.01 & 0.04 \\
\hline & $(0.93)$ & $(1.24)$ & $(1.21)$ & $(1.47)$ & $(1.17)$ & $(1.46)$ & $(0.11)$ & $(0.29)$ \\
\hline Observations & 691 & 691 & 691 & 691 & 691 & 691 & 691 & 691 \\
\hline Controls & & $\boldsymbol{V}$ & & $\sqrt{ }$ & & $\mathbf{V}$ & & $\mathbf{v}$ \\
\hline
\end{tabular}

Notes: The dependent variable is equal to one if the three main crops cultivated by the individual in 2010 were not crops that the individual cultivated during the first round of the survey. All coefficients come from separate estimations and are the coefficients for the measure of the intensity of the forced migration shock. t-statistics are reported in parenthesis. $* * *$ indicates significant at $1 \%$ level, $* *$ indicates significant at $5 \%$ level, $*$ indicates significant at $10 \%$ level. 
Table 6 - Impact of being a temporary worker during pre-shock period on main economic activities in 2010

\begin{tabular}{|c|c|c|c|c|c|c|c|c|c|}
\hline \multirow{4}{*}{$\begin{array}{l}\text { Dependent variable } \\
\text { Farming/livestock }\end{array}$} & \multirow{4}{*}{$\begin{array}{c}\text { Impact of } \\
\text { Pre-shock temporary work }\end{array}$} & & ensity of & ed migrati & hock (i.e. lo & (distance)) c & tructed wit & stance to: & \\
\hline & & \multicolumn{2}{|c|}{ Burundi } & \multicolumn{2}{|c|}{ Rwanda } & \multicolumn{2}{|c|}{ Weighted } & \multicolumn{2}{|c|}{ Camps } \\
\hline & & -0.28 & -0.14 & -0.28 & -0.10 & -0.28 & -0.12 & -0.26 & -0.08 \\
\hline & & $(-3.26)^{* * *}$ & $(-1.43)$ & $(-2.43)^{* *}$ & $(-0.91)$ & $(-2.82)^{* * *}$ & $(-1.14)$ & $(-1.35)$ & $(-0.40)$ \\
\hline \multirow[b]{3}{*}{ Self-employment } & \multirow{2}{*}{ Interaction } & -0.01 & -0.00 & -0.01 & 0.01 & -0.01 & 0.00 & -0.01 & 0.01 \\
\hline & & $(-0.61)$ & $(-0.09)$ & $(-0.47)$ & $(0.26)$ & $(-0.56)$ & $(0.12)$ & $(-0.19)$ & $(0.22)$ \\
\hline & \multirow{2}{*}{ Pre-shock temporary work } & 0.28 & 0.18 & 0.28 & 0.17 & 0.31 & 0.20 & 0.43 & 0.31 \\
\hline & & $(3.32)^{* * *}$ & $(1.92)^{*}$ & $(3.68)^{* * *}$ & $(2.03)^{* *}$ & $(3.99)^{* * *}$ & $(2.17)^{* *}$ & $(2.07)^{* *}$ & $(1.58)$ \\
\hline \multirow{6}{*}{ Employee } & \multirow{2}{*}{ Interaction } & 0.08 & 0.07 & 0.09 & 0.07 & 0.09 & 0.08 & 0.09 & 0.08 \\
\hline & & $(4.20)^{* * *}$ & $(3.44)^{* * *}$ & $(4.37)^{* * *}$ & $(3.54)^{* * *}$ & $(4.76)^{* * *}$ & $(3.64)^{* * *}$ & $(2.43)^{* *}$ & $(2.23)^{* *}$ \\
\hline & \multirow{2}{*}{ Pre-shock temporary work } & -0.00 & -0.05 & -0.01 & -0.08 & -0.04 & -0.10 & -0.20 & -0.28 \\
\hline & & $(-0.02)$ & $(-0.60)$ & $(-0.11)$ & $(-0.77)$ & $(-0.40)$ & $(-1.07)$ & $(-0.92)$ & $(-1.27)$ \\
\hline & \multirow{2}{*}{ Interaction } & -0.07 & -0.07 & -0.08 & -0.09 & -0.09 & -0.09 & -0.09 & -0.09 \\
\hline & & $(-3.47)^{* * *}$ & $(-3.79)^{* * *}$ & $(-3.01)^{* * *}$ & $(-3.46)^{* * *}$ & $(-3.76)^{* * *}$ & $(-4.11)^{* * *}$ & $(-2.42)^{* *}$ & $(-2.58)^{* * *}$ \\
\hline Observations & & 1,005 & 1,005 & 1,005 & 1,005 & 1,005 & 1,005 & 1,005 & 1,005 \\
\hline Controls & & & v & & v & & $\mathbf{v}$ & & v \\
\hline
\end{tabular}

Notes: The dependent variables reflect the main activity choices of the individuals in the sample: working in household shambas/livestock, non-farm self-

employment or working for someone outside the household. Pre-shock temporary work is equal to one if the individual identified his/her job as

"temporary" in the first round of the survey. All coefficients come from separate estimations. The coefficients shown are for the pre-shock temporary work variable and for the interaction of this variable with the measures of the intensity of the forced migration shock. $t$-statistics are reported in parenthesis. $* * *$ indicates significant at $1 \%$ level, ** indicates significant at $5 \%$ level, * indicates significant at $10 \%$ level. 
Table 7 - Impact of being a temporary worker during pre-shock period on being an agricultural and non-agricultural employee in 2010

\begin{tabular}{|c|c|c|c|c|c|c|c|c|c|}
\hline \multirow{4}{*}{$\begin{array}{l}\text { Dependent variable } \\
\text { Agricultural employee }\end{array}$} & & \multicolumn{8}{|c|}{ Intensity of the forced migration shock (i.e. $\log (1 /$ distance)) constructed with distance to: } \\
\hline & Impact of & \multicolumn{2}{|c|}{ Burundi } & \multicolumn{2}{|c|}{ Rwanda } & \multicolumn{2}{|c|}{ Weighted } & \multicolumn{2}{|c|}{ Camps } \\
\hline & & 0.02 & 0.01 & -0.01 & -0.02 & 0.00 & -0.01 & -0.06 & -0.08 \\
\hline & Pre-snock temporary work & (0.29) & $(0.14)$ & $(-0.09)$ & $(-0.26)$ & $(0.05)$ & $(-0.09)$ & $(-0.49)$ & $(-0.58)$ \\
\hline \multirow{5}{*}{ Non-agricultural employee } & \multirow{2}{*}{ Interaction } & -0.03 & -0.03 & -0.03 & -0.04 & -0.03 & -0.03 & -0.03 & -0.04 \\
\hline & & $(-1.60)$ & $(-1.54)$ & $(-1.81)^{*}$ & $(-1.78)^{*}$ & $(-1.63)$ & $(-1.58)$ & $(-1.53)$ & $(-1.50)$ \\
\hline & & -0.02 & -0.06 & -0.01 & -0.06 & -0.04 & -0.09 & -0.14 & -0.19 \\
\hline & Pre-shock temporary work & $(-0.18)$ & $(-0.55)$ & $(-0.04)$ & $(-0.50)$ & $(-0.38)$ & $(-0.83)$ & $(-0.51)$ & $(-0.71)$ \\
\hline & Interaction & -0.05 & -0.05 & -0.05 & -0.05 & -0.06 & -0.06 & -0.06 & -0.06 \\
\hline Observations & & 1,005 & 1,005 & 1,005 & 1,005 & 1,005 & 1,005 & 1,005 & 1,005 \\
\hline Controls & & & $\sqrt{ }$ & & $\mathbf{V}$ & & $\boldsymbol{V}$ & & v \\
\hline
\end{tabular}

Notes: The dependent variables reflect the type of employment (agricultural, non-agricultural) of those who have employment outside the household as their main economic activity. Pre-shock temporary work is equal to one if the individual identified his/her job as "temporary" in the first round of the survey. All coefficients come from separate estimations. The coefficients shown are for the pre-shock temporary work variable and for the interaction of this variable with the measures of the intensity of the forced migration shock. $t$-statistics are reported in parenthesis. ${ }^{* * *}$ indicates significant at $1 \%$ level, ** indicates significant at $5 \%$ level, * indicates significant at $10 \%$ level. 
Table 8 - Regression results for main economic activities for those individuals younger than 16 years of age in first round (without interaction terms).

\begin{tabular}{|c|c|c|c|c|c|c|c|c|}
\hline \multirow{2}{*}{$\begin{array}{l}\text { Dependent variable } \\
\text { Farming/livestock }\end{array}$} & \multicolumn{8}{|c|}{ Intensity of the forced migration shock (i.e. $\log (1 /$ distance)) constructed with distance to: } \\
\hline & $\begin{array}{l}-0.02 \\
(-0.68)\end{array}$ & $\begin{array}{l}-0.02 \\
(-0.88)\end{array}$ & $\begin{array}{c}-0.05 \\
(-1.92)^{*}\end{array}$ & $\begin{array}{c}-0.04 \\
(-1.66)^{*}\end{array}$ & $\begin{array}{c}-0.04 \\
(-1.47)\end{array}$ & $\begin{array}{l}-0.03 \\
(-1.44)\end{array}$ & $\begin{array}{c}0.00 \\
(0.03)\end{array}$ & $\begin{array}{c}0.01 \\
(0.26)\end{array}$ \\
\hline Self-employment & $\begin{array}{l}-0.01 \\
(-0.38)\end{array}$ & $\begin{array}{c}-0.01 \\
(-0.24)\end{array}$ & $\begin{array}{c}0.02 \\
(0.74)\end{array}$ & $\begin{array}{c}0.02 \\
(0.63)\end{array}$ & $\begin{array}{c}0.01 \\
(0.43)\end{array}$ & $\begin{array}{c}0.01 \\
(0.42)\end{array}$ & $\begin{array}{l}-0.01 \\
(-0.31)\end{array}$ & $\begin{array}{l}-0.01 \\
(-0.17)\end{array}$ \\
\hline Employee & $\begin{array}{c}0.06 \\
(2.11)^{* *}\end{array}$ & $\begin{array}{c}0.06 \\
(2.27)^{* *}\end{array}$ & $\begin{array}{c}0.06 \\
(2.37)^{* *}\end{array}$ & $\begin{array}{c}0.06 \\
(2.11)^{* *}\end{array}$ & $\begin{array}{c}0.06 \\
(2.32)^{* *}\end{array}$ & $\begin{array}{c}0.06 \\
(2.24)^{* *}\end{array}$ & $\begin{array}{c}0.04 \\
(0.92)\end{array}$ & $\begin{array}{c}0.03 \\
(0.73)\end{array}$ \\
\hline Agricultural employee & $\begin{array}{c}0.05 \\
(2.50)^{* *}\end{array}$ & $\begin{array}{c}0.05 \\
(2.64)^{* * *}\end{array}$ & $\begin{array}{c}0.04 \\
(2.63)^{* * *}\end{array}$ & $\begin{array}{c}0.04 \\
(2.66)^{* * *}\end{array}$ & $\begin{array}{c}0.05 \\
(2.65)^{* * *}\end{array}$ & $\begin{array}{c}0.05 \\
(2.77)^{* * *}\end{array}$ & $\begin{array}{c}0.07 \\
(1.85)^{*}\end{array}$ & $\begin{array}{c}0.07 \\
(1.77)^{*}\end{array}$ \\
\hline Non-agricultural employee & $\begin{array}{c}0.00 \\
(0.12)\end{array}$ & $\begin{array}{c}0.00 \\
(0.10)\end{array}$ & $\begin{array}{c}0.02 \\
(0.89)\end{array}$ & $\begin{array}{c}0.01 \\
(0.60)\end{array}$ & $\begin{array}{c}0.01 \\
(0.49)\end{array}$ & $\begin{array}{c}0.01 \\
(0.32)\end{array}$ & $\begin{array}{c}-0.03 \\
(-1.22)\end{array}$ & $\begin{array}{l}-0.04 \\
(-1.41)\end{array}$ \\
\hline Observations & \multicolumn{8}{|c|}{ (B) Younger than 7 years of age } \\
\hline Farming/livestock & $\begin{array}{l}-0.10 \\
(-1.08)\end{array}$ & $\begin{array}{c}-0.07 \\
(-0.83)\end{array}$ & $\begin{array}{c}-0.15 \\
(-1.85)^{*}\end{array}$ & $\begin{array}{c}-0.12 \\
(-1.61)\end{array}$ & $\begin{array}{c}-0.14 \\
(-1.55)\end{array}$ & $\begin{array}{c}-0.11 \\
(-1.26)\end{array}$ & $\begin{array}{c}0.01 \\
(0.08)\end{array}$ & $\begin{array}{c}0.07 \\
(1.03)\end{array}$ \\
\hline Self-employment & $\begin{array}{c}0.01 \\
(0.36)\end{array}$ & $\begin{array}{c}0.00 \\
(0.09)\end{array}$ & $\begin{array}{c}0.03 \\
(1.09)\end{array}$ & $\begin{array}{c}0.02 \\
(0.63)\end{array}$ & $\begin{array}{c}0.03 \\
(0.98)\end{array}$ & $\begin{array}{c}0.02 \\
(0.55)\end{array}$ & $\begin{array}{l}-0.00 \\
(-0.04)\end{array}$ & $\begin{array}{c}-0.02 \\
(-0.64)\end{array}$ \\
\hline Employee & $\begin{array}{c}0.16 \\
(2.17)^{* *}\end{array}$ & $\begin{array}{c}0.14 \\
(2.11)^{* *}\end{array}$ & $\begin{array}{c}0.19 \\
(3.25)^{* * *}\end{array}$ & $\begin{array}{c}0.18 \\
(3.28)^{* * *}\end{array}$ & $\begin{array}{c}0.18 \\
(2.84)^{* * *}\end{array}$ & $\begin{array}{c}0.17 \\
(2.83)^{* * *}\end{array}$ & $\begin{array}{c}0.05 \\
(0.75)\end{array}$ & $\begin{array}{l}-0.00 \\
(-0.05)\end{array}$ \\
\hline Agricultural employee & $\begin{array}{c}0.15 \\
(2.99)^{* * *}\end{array}$ & $\begin{array}{c}0.15 \\
(2.95)^{* * *}\end{array}$ & $\begin{array}{c}0.15 \\
(4.25)^{* * *}\end{array}$ & $\begin{array}{c}0.15 \\
(4.14)^{* * *}\end{array}$ & $\begin{array}{c}0.15 \\
(3.67)^{* * *}\end{array}$ & $\begin{array}{c}0.15 \\
(3.63)^{* * *}\end{array}$ & $\begin{array}{c}0.09 \\
(2.09)^{* *}\end{array}$ & $\begin{array}{c}0.08 \\
(2.03)^{* *}\end{array}$ \\
\hline Non-agricultural employee & $\begin{array}{c}0.01 \\
(0.27)\end{array}$ & $\begin{array}{c}-0.00 \\
(-0.11)\end{array}$ & $\begin{array}{c}0.04 \\
(1.14)\end{array}$ & $\begin{array}{c}0.03 \\
(0.86)\end{array}$ & $\begin{array}{c}0.03 \\
(0.86)\end{array}$ & $\begin{array}{c}0.02 \\
(0.45)\end{array}$ & $\begin{array}{c}-0.05 \\
(-1.15)\end{array}$ & $\begin{array}{c}-0.09 \\
(-2.02)^{* *}\end{array}$ \\
\hline Observations & 648 & 648 & 648 & 648 & 648 & 648 & 648 & 648 \\
\hline Controls & & $\mathbf{v}$ & & $\mathbf{v}$ & & $\mathbf{v}$ & & $\sqrt{ }$ \\
\hline
\end{tabular}

Notes: The dependent variables reflect the main activity choices of the individuals in the sample: working in household shambas/livestock, non-farm selfemployment, working in agriculture for someone outside the household and working in a non-agricultural job for someone outside the household. All coefficients come from separate estimations and are the coefficients for the measure of the intensity of the forced migration shock in a linear probability model. The information only includes outcomes in 2010. t-statistics are reported in parenthesis. ${ }^{* * *}$ indicates significant at $1 \%$ level, ${ }^{* *}$ indicates significant at $5 \%$ level, * indicates significant at $10 \%$ level. 